\title{
PENGEMBANGAN LEMBAR KERJA MAHASISWA BERBASIS REACT (RELATING, EXPERIENCING, APPLYING, COOPERATING, TRANSFERING) PADA TUTORIAL STATISTIKA PENDIDIKAN DI UNIVERSITAS TERBUKA
}

\author{
Tri Dyah Prastiti ${ }^{\mathrm{a}}$, Yumiati ${ }^{\mathrm{b}}$, Jackson Pasini Mairing $^{\mathrm{c}}$, Estu Puji Handayani ${ }^{\mathrm{d}}$ \\ ${ }^{a}$ Program Studi Pendidikan Matematika FKIP Universitas Terbuka \\ Jl. Kaliurang 2A Jember, tridyahprastiti@ecampus.ut.ac.id \\ ${ }^{\text {b} P r o g r a m ~ S t u d i ~ P e n d i d i k a n ~ M a t e m a t i k a ~ F K I P ~ U n i v e r s i t a s ~ T e r b u k a ~}$ \\ Jl. Cabe Raya Pondok Cabe, Tangerang, yumiati@ecampus.ut.ac.id \\ ${ }^{\mathrm{c}}$ Program Studi Pendidikan Matematika Universitas Palangka Raya \\ Jl. H. Timang Kampus UPR, Palangka Raya, jacksonmairing@gmail.com \\ ${ }^{\mathrm{d}}$ Program Studi Pendidikan Matematika Universitas Terbuka \\ Jl. Kaliurang 2A Jember, bundaways@gmail.com
}

\begin{abstract}
ABSTRAK
Penelitian ini bertujuan mengembangkan Lembar Kerja Mahasiswa (LKM) berbasis strategi REACT (Relating, Experiencing, Applying, Cooperating, Transfering) untuk tutorial Statistika Pendidikan bagi mahasiswa UT, yang valid, praktis dan efektif. Pendekatan tutorial dengan menggunakan LKM berbasis REACT ini diharapkan dapat meningkatkan motivasi belajar mahasiswa dan memudahkan mahasiswa secara konseptual memahami Statistik Pendidikan serta meningkatkan kemampuan dalam mengerjakan soal-soal sehingga dapat meningkatkan hasil belajar. Jenis penelitian adalah penelitian pengembangan (developmental research) dengan pendekatan kuantitatif. Subjek penelitian 40 mahasiswa UPBJJ-UT Jember Program S1 PGSD yang mengambil mata kuliah Statistika Pendidikan. Pengembangan LKM menggunakan tahap Plomp yang terdiri dari (1) penelitian awal, (2) perancangan, (3) realisasi/konstruksi, (4) tes, evaluasi dan revisi, dan (5) implementasi. Hasil penelitian menunjukkan bahwa LKM berbasis REACT yang dikembangkan dalam penelitian ini telah memenuhi kriteria valid, praktis dan efektif. Lebih lanjut, hasil angket menunjukkan bahwa $76 \%$ mahasiswa merasa senang, dan $81 \%$ mahasiswa termotivasi belajar mandiri setelah belajar dengan pembelajaran berbasis strategi REACT.
\end{abstract}

Kata kunci : REACT, Statistika Pendidikan, pemahaman konseptual, motivasi.

\begin{abstract}
This research was aimed to develop a valid, practical and efficient REACT (Relating, Experiencing, Applying, Cooperating, and Transfering) based student worksheet on Statistics Education for Universitas Terbuka's students. Tutorial approach using REACT based student worksheet was hoped to escalate students' motivation to learn, simplify conceptual understanding on Statistics Education while also improving the ability to do the tasks so that better learning result would be achieved. Developmental research was used with quantitative approach. Subjects of this research were 40 UPBJJ UT Jember students who take Statistics Education course. Development of worksheet was using Plomp phase which consist of (1) early research, (2) designing, (3) realization/construction, (4) test, evaluation and revison, and (5) implementation. Results showed that REACT based worksheet that developed on this research has fulfilled validity, practical, and effectiveness criteria. Moreover, survey showed that $76 \%$ of students felt happy, and $81 \%$ of students were motivated to learn independently after doing REACT strategy based learning
\end{abstract}

Keywords: REACT , Statistics Education, conceptual understanding, motivation. 


\section{Pendahuluan}

Salah satu mata kuliah yang wajib ditempuh oleh mahasiswa Program Studi PGSD di Universitas Terbuka adalah Statistika Pendidikan. Matakuliah Statistika Pendidikan membahas mengenai dasar-dasar statistika, penyajian data dalam bentuk tabel dan diagram, ukuran pemusatan, lokasi dan dispersi, serta ukuran kemiringan dan keruncingan, distribusi normal dan kegunaannya, pengujian hipotesis, analisis regresi, dan korelasi.

Jika dilihat materi-materi yang harus dipelajari, maka mempelajari Statistik Pendidikan ini menuntut mahasiswa memiliki pengetahuan prasyarat tertentu. Pengetahuan tersebut antara lain pengetahuan tentang data yang dilihat dalam kehidupan sehari hari, operasi aljabar termasuk menghitung logaritma. Bagi mahasiswa UT untuk program Studi PGSD yang juga merupakan guru-guru $\mathrm{SD}$, mata kuliah ini dianggap sulit oleh mahasiswa UT.

Suatu mata kuliah yang dianggap sulit akan menyebabkan motivasi mahasiswa dalam belajar yang rendah. Motivasi yang rendah ini dapat menyebabkan mahasiswa malas dalam mempelajari modul, malas dalam menyelesaikan soalsoal dalam modul, dan malas dalam menyelesaikan tugas tutorial secara mandiri. Sikap yang demikian dapat berdampak pada rendahnya hasil belajar mahasiswa pada mata kuliah ini.

Kondisi seperti yang dijelaskan di atas, perlu dicari solusinya agar motivasi dan hasil belajar mahasiswa meningkat di tahun-tahun ajaran berikutnya. Salah satu caranya adalah tutor menggunakan bahan belajar suplemen yang dapat membantu mahasiswa dalam memahami materimateri pada buku materi pokok Statistika Pendidikan. Bahan belajar suplemen tersebut dapat berupa Lembar Kerja Mahasiswa (LKM). Penggunaan LKM diharapkan dapat membantu mahasiswa memahami materi-materi dalam matakuliah Statistika Pendidikan. Ini dapat terjadi jika materi-materi disusun sedemikian rupa sehingga mahasiswa dapat mengaitkan materi ini dengan kehidupan nyata dan pengetahuan sebelumnya yang sudah ada dalam pikiran mahasiswa. Salah satu teori belajar yang demikian adalah pembelajaran kontekstual (Nurhadi, 2004).

Pembelajaran kontekstual menurut Contextual teaching Exchange (CTN, 2001: 1) mendasarkan pada suatu kenyataan bahwa sebagian besar pembelajaran yang telah dilaksanakan 
bersifat tradisional dan tanpa "konteks". Hal ini berakibat siswa dalam belajarnya hanya mengingat algoritma, prosedur dan fakta serta konsep-konsep yang abstrak. Indikasi lain yang muncul adalah bahwa "skill drill" atau kemampuan mengerjakan latihan bertujuan untuk mengingat prosedur dari suatu konsep, kemudian penilaian tutor didasarkan pada kemampuan siswa mengerjakan drill tersebut. Akibatnya pembelajaran seperti ini hanya menghasilkan pemerolehan konsep di benak siswa yang tanpa makna. Oleh karena itu, menurut Bransford, Brown, and cocking dalam CTN (2001:1) strategi pembelajaran yang dilaksanakan oleh tutor haruslah membantu siswa membangun kedalaman pemahaman atas konsep-konsep penting. Hal ini didukung oleh pendapat Crawford (1999) bahwa tujuan akhir dari suatu pembelajaan yang kontekstual adalah memunculkan kemampuan siswa untuk mentransfer pengetahuan pada situasi baru dan menumbuhkan motivasi belajar serta kepercayaan diri siswa.

Salah satu strategi dalam pembelajaran kontekstual adalah REACT (Relating, Experiencing, Applying, Cooperating, Transferring). Strategi ini pertama kali diungkap oleh Center of Occupational Research and Development (CORD: 2001). Jika diterjemahkan ke dalam bahasa Indonesia, REACT berarti pengaitan, pengalaman, penerapan, bekerjama dan pentransferan. Ada beberapa keunggunalan dari penggunaan strategi ini dalam pembelajaran yaitu (a) dapat memotivasi mahasiswa dalam belajar, (b) meningkatkan hasil belajar mahasiswa, (c) mendorong mahasiswa memiliki pemahaman yang mendalam dan alasan belajar, (d) mengembangkan sikap positif mahasiswa, (e) mengembangkan sikap menghargai diri sendiri dan orang lain, (f) membuat belajar lebih efektif, (g) mengembangkan rasa saling memiliki, (h) mengembangkan keterampilan untuk masa depan, (i) mengembangkan sikap mencintai dan berorientasi pada lingkungan, dan (j) mampu menjelaskan pentingnya materi dan aplikasinya secara langsung dalam kehidupan sehari-hari (Crawford, 1999; CORD, 2001).

Berdasarkan uraian di atas, peneliti akan mengembangkan LKM berbasis REACT sebagai solusi untuk permasalahan tutorial matakuliah Statistika Pendidikan dalam kelas. Peneliti mengembangkan LKM untuk menyediakan sumber belajar yang dapat membantu mahasiswa memiliki pemahaman yang mendalam dan dapat meningkatkan hasil belajarnya. Berdasarkan keunggulan-keunggulan strategi REACT, maka peneliti memilih strategi ini dalam memngembangkan LKM tersebut. 
Berdasarkan uraian di atas maka rumusan masalah dalam penelitian ini adalah: "bagaimana mengembangkan Lembar Kerja Mahasiswa berbasis strategi REACT (Relating, Experiencing, Applying, Cooperating, Transferring) pada tutorial Statistika Pendidikan yang valid, praktis dan efektif?". LKM dikatakan valid jika tiga dari empat ahli menyatakan setuju atau sangat setuju bahwa (a) materi dari LKM sesuai dengan teori-teori Statistika Pendidikan, dan (b) penyajian materi dalam LKM didasarkan pada strategi REACT. LKM dikatakan praktis jika (a) tutor dapat melaksanakan setidaknya $80 \%$ kegiatan dalam SAT di setiap pertemuan, (b) semua modul dalam LKM dapat diselesaikan dalam 8 kali tutorial tatap muka. LKM dikatakan efektif jika (a) mahasiswa dapat menjawab setidaknya $80 \%$ pertanyaan/soal/tugas dalam LKM, (b) Rata-rata hasil belajar mahasiswa minimal 70, (c) Setidaknya $70 \%$ mahasiswa berpendapat setuju atau sangat setuju bahwa LKM dapat membantu mahasiswa dalam memahami konsep-konsep dalam mata kuliah Statistika Pendidikan.

Manfaat praktis dari penelitian ini adalah tutor dapat mengembangkan kemampuan profesionalitasnya dalam mengembangkan sumber-sumber belajar berbasis pembelajaran kontekstual khususnya strategi REACT. Salah satu sumber belajar yang dapat dikembangkan tutor adalah lembar kerja mahasiswa (LKM). Pada proses pengembangannya, tutor mengimplementasi LKM tersebut pada tutorial suatu kelas tertentu. Pengimplementasian itu sendiri dapat membantu tutor memiliki kemampuan dalam menciptakan pembelajaranpembelajaran yang aktif, inovatif, kreatif, efektif dan menyenangkan.

Luaran dari penelitian ini yang berupa LKM dapat digunakan bukan hanya oleh peneliti tetapi juga oleh tutor-tutor lainnya yang mengampu matakuliah Statistika Pendidikan. Harapannya penggunaan LKM ini dalam kegiatan tutorial dapat menciptakan pembelajaran yang menyenangkan. Pembelajaran demikian dapat mendorong peningkatan hasil belajar mahasiswa. Peningkatan hasil belajar ini akan berdampak langsung pada peningkatan kualitas pembelajaran di Universitas Terbuka.

Secara teoritik manfaat yang dapat dipetik dari hasil penelitian ini adalah memberikan latar belakang dan landasan teoritik tentang bagaimana mengembangkan suatu produk pendidikan yang bermanfaat dalam menciptakan pembelajaran yang aktif, kreatif, efektif dan menyenangkan. Pembelajaran yang demikian diharapkan dapat membantu mahasiswa memiliki 
pengetahuan konseptual. Mahasiswa yang memiliki pengetahuan konseptual akan lebih mampu dalam belajar sesuatu yang baru dan mampu dalam memecahkan masalah.

\section{Metode Penelitian}

Tujuan penelitian ini adalah mengembangkan Lembar Kerja Mahasiswa (LKM) berbasis strategi REACT (Relating, Experiencing, Applying, Cooperating, Transfering) pada mata kuliah Statistika Pendidikan yang valid, praktis dan efektif. Data yang dibutuhkan untuk mencapai tujuan tersebut adalah data: (1) hasil belajar mahasiswa, (2) respons mahasiswa yang dijaring menggunakan angket, pendapat para ahli yang diiperoleh menggunakan Lembar Penilaian Ahli dan (4) hasil pengamatan aktivitas tutor yang diperoleh menggunakan Lembar Pengamatan. Keempat data tersebut berupa bilangan. Dengan demikian, peneliti menggunakan pendekatan kuantitatif untuk memperoleh data penelitian yang selanjutnya digunakan untuk mencapai tujuan penelitian.

Salah satu luaran dari penelitian ini adalah LKM. LKM tersebut dikembangkan menggunakan tahap-tahap pengembangan produk yang dikemukakan Plomp (1997). Dengan kata lain, penelitian ini menghasilkan suatu produk pendidikan tertentu yaitu LKM.
Jadi, jenis penelitian ini adalah penelitian pengembangan.

Subjek penelitian ini adalah mahasiswa program studi PGSD UPBJJ Universitas Terbuka Jember Pokjar Bondowoso yang mengambil matakuliah Statistika Pendidikan (PEMA4210) masa registrasi 2016.2. Penelitian ini dilaksanakan mulai bulan Maret s.d Desember 2016. Tempat penelitiannya adalah Pokjar Bondowoso UPPBJ UT Jember.

\section{TAHAP INVESTIGASI AWAL}

Peneliti mengidentifikasi masalah.

Hasil:

Masalah: ada $40 \%$ mahasiswa yang tidak lulus.

Akar penyebab: belajar yang didominasi tutor dan kurangnya sumber belajar

\section{TAHAP DESAIN}

Peneliti mengembangkan tutorial kit dan instrumen penelitian

Hasil:

Desain tutorial kit dan instrumen penelitian

\section{TAHAP REALISASI / KOSNTRUKSI}

Peneliti merealisasi yang telah didesain sebelumnya. Hasil:

Tutorial kit : RAT, SAT, RE dan LKM berbasis REACT

Instrumen penelitian : Lembar Pengamatan Aktivtias Tutor, Lembar Penilaian Ahli, Angket Mahasiswa dan Tes Hasil Belajar

\section{TAHAP TES, EVALUASI \& REVISI}

1. LKM dievaluasi oleh 3 ahli

2. Peneliti merevisi berdasarkan masukkan 3 ahli tersebut

Hasil:

Draft 1 LKM

\section{TAHAP IMPLEMENTASI}

Peneliti mengimplementasi Draft 1 LKM berbasis

REACT pada subjek penelitian

Hasil :

LKM BERBASIS REACT

Gambar 1. Prosedur Pengembangan

LKM berbasis REACT 
Tabel 1. Data-data Penelitian beserta Teknik Analisisnya

\begin{tabular}{|c|c|c|c|c|}
\hline & Kriteria & $\begin{array}{c}\text { Data yang } \\
\text { Dibutuhkan }\end{array}$ & $\begin{array}{l}\text { Instrumen } \\
\text { Pengumpul } \\
\text { Data }\end{array}$ & Teknik Analisis Data \\
\hline $\begin{array}{l}\text { Kev } \\
\text { (a) } \\
\text { (b) }\end{array}$ & $\begin{array}{l}\text { alidan } \\
\text { materi dari LKM sesuai } \\
\text { dengan teori-teori Statistika } \\
\text { Pendidikan, } \\
\text { penyajian materi dalam } \\
\text { LKM didasarkan pada } \\
\text { strategi REACT. }\end{array}$ & $\begin{array}{l}\text { Data penilaian } \\
\text { para ahli: } \\
\text { 1=STS, } 2=\mathrm{TS}, \\
3=\mathrm{S} \text {, dan } 4=\mathrm{SS}\end{array}$ & $\begin{array}{l}\text { Lembar } \\
\text { Penilaian } \\
\text { Ahli }\end{array}$ & $\begin{array}{l}\text { 1. Data disajikan dalam bentuk tabel } \\
\text { dan grafik. } \\
\text { 2. Data dibandingkan dengan kriteria } \\
\text { kualitas LKM }\end{array}$ \\
\hline $\begin{array}{l}\text { Kep } \\
\text { (a) } \\
\text { (b) }\end{array}$ & $\begin{array}{l}\text { raktisan } \\
\text { tutor dapat melaksanakan } \\
\text { setidaknya } 80 \% \text { kegiatan } \\
\text { dalam SAT di setiap } \\
\text { pertemuan, } \\
\text { semua modul dalam LKM } \\
\text { dapat diselesaikan dalam } 8 \\
\text { kali tutorial tatap muka. }\end{array}$ & $\begin{array}{l}\text { Data hasil } \\
\text { pengamatan } \\
\text { oleh observer: } \\
0=\text { tidak } \\
\text { dilaksanakan } \\
1=\text { dilaksa- } \\
\text { nakan }\end{array}$ & $\begin{array}{l}\text { Lembar } \\
\text { Pengamatan } \\
\text { Aktivitas } \\
\text { Tutor }\end{array}$ & $\begin{array}{l}\text { 1. Data disajikan dalam bentuk tabel } \\
\text { dan grafik. } \\
\text { 2. Data disajikan dalam bentuk rata- } \\
\text { rata atau persentase. } \\
\text { 3. Data dibandingkan dengan kriteria } \\
\text { kualitas LKM }\end{array}$ \\
\hline & $\begin{array}{l}\text { fektifan } \\
\text { mahasiswa dapat menjawab } \\
\text { setidaknya } 80 \% \\
\text { pertanyaan/soal/ tugas } \\
\text { dalam LKM, }\end{array}$ & $\begin{array}{l}\text { Jawaban } \\
\text { mahasiswa } \\
\text { dalam LKM }\end{array}$ & $\begin{array}{l}\text { LKM } \\
\text { berbasis } \\
\text { REACT }\end{array}$ & $\begin{array}{l}\text { 1. Data jawaban mahasiswa dalam } \\
\text { LKM discan dan ditampilkan apa } \\
\text { adanya, selanjutnya diberi makna } \\
\text { 2. Data disajikan dalam bentuk rata- } \\
\text { rata atau persentase. } \\
\text { 3. Data dibandingkan dengan kriteria } \\
\text { kualitas LKM }\end{array}$ \\
\hline (b) & $\begin{array}{l}\text { Rata-rata hasil belajar } \\
\text { mahasiswa minimal } 70 \text {, }\end{array}$ & Skor mahasiswa & $\begin{array}{l}\text { Tugas } 1,2,3 \\
\text { dan Tes Hasil } \\
\text { Belajar }\end{array}$ & $\begin{array}{l}\text { 1. Data disajikan dalam bentuk rata- } \\
\text { rata atau persentase. } \\
\text { 2. Data dibandingkan dengan kriteria } \\
\text { kualitas LKM }\end{array}$ \\
\hline (c) & $\begin{array}{l}\text { Setidaknya } 70 \% \text { mahasiswa } \\
\text { berpendapat setuju atau } \\
\text { sangat setuju bahwa LKM } \\
\text { dapat membantu mahasiswa } \\
\text { dalam memahami konsep- } \\
\text { konsep dalam mata kuliah } \\
\text { Statistika Pendidikan. }\end{array}$ & $\begin{array}{l}\text { Data Angket: } \\
1=\mathrm{STS}, 2=\mathrm{TS}, \\
3=\mathrm{S} \text {, dan } 4=\mathrm{SS}\end{array}$ & $\begin{array}{l}\text { Tugas } 1,2,3 \\
\text { dan Tes Hasil } \\
\text { Belajar } \\
\text { Angket } \\
\text { Mahasiswa }\end{array}$ & $\begin{array}{l}\text { 1. Data disajikan dalam bentuk tabel } \\
\text { dan grafik. } \\
\text { 2. Data disajikan dalam bentuk rata- } \\
\text { rata atau persentase. } \\
\text { 3. Data dibandingkan dengan kriteria } \\
\text { kualitas LKM }\end{array}$ \\
\hline
\end{tabular}

Pengembangan LKM berbasis

REACT ini menggunakan tahap-tahap pengembangan produk pendidikan Plomp (1997: 5). Tahap pengembangan ini secara umum terdiri dari empat tahap yaitu (1) investigasi awal, (2) desain, (3) realisasi/konstruksi, (4) tes, evaluasi dan revisi dan (5) implementasi. Secara rinci prosedur pengembangan LKM berbaais REACT ini dapat dilihat pada Gambar 1. Teknik analisis data dalam penelitian ini secara umum dilakukan secara deskriptif dan dengan membandingkan data yang diperoleh dengan kriteria valid, praktis dan efektif 
yang telah ditentukan sebelumnya (Tabel $1)$.

\section{Hasil Penelitian dan Pembahasan}

Tujuan penelitian adalah mengembangkan Lembar Kerja Mahasiswa (LKM) berbasis strategi REACT (Relating, Experiencing, Applying, Cooperating, Transfering) pada tutorial Statistika Pendidikan mahasiswa UT, yang valid, praktis dan efektif. LKM yang dikembangkan bertujuan untuk mengatasi masalahmasalah pada tutorial mata kuliah Statistika Pendidikan. Masalah-masalah tersebut terjadi karena kurangnya sumber belajar yang dapat membantu mahasiswamahasiswa UT yang dapat memotivasi mahasiswa untuk belajar mandiri sehingga memiliki pemahaman mendalam terhadap konsep-konsep dan prosedur-prosedur dalam Statistika Pendidikan.

Tahap awal dalam pengembangan tersebut adalah peneliti mendesain tutorial kit dan instrumen penelitian. Tutorial kit tersebut adalah Rancangan Aktivitas Tutorial, Satuan Aktivitas Tutorial, Lembar Kerja Mahasiswa berbasis REACT, dan Rancangan Evaluasi. Instrumenya adalah Lembar Penilaian Ahli, Lembar Pengamatan Aktivitas Tutor, dan Angket Mahasiswa.

Desain penelitian yang telah dikembangkan sebelumnya direalisasikan oleh peneliti. Hasil realisasi tersebut dinilai oleh tiga validator (ahli). Ketiga validator tersebut memberikan masukanmasukan guna perbaikan tutorial kit terutama pada LKM mahasiswa berbasis REACT. Setelah itu, perbaikan tersebut kembali dinilai oleh tiga ahli. Hasilnya menunjukkan bahwa ketiga ahli tersebut menyatakan setuju atau sangat setuju bahwa materi dari LKM sesuai dengan teori-teori Statistika Pendidikan, dan penyajian materi dalam LKM didasarkan pada strategi REACT (Tabel 2).

Tabel 2. Hasil Penilaian Tiga Ahli

\begin{tabular}{|c|c|c|c|c|}
\hline \multirow[t]{2}{*}{ No } & \multirow[t]{2}{*}{ Uraian } & \multicolumn{3}{|c|}{ Validator } \\
\hline & & 1 & 2 & 3 \\
\hline 1 & $\begin{array}{l}\text { Kejelasan deskripsi mata } \\
\text { kuliah dalam LKM }\end{array}$ & 4 & 3 & 4 \\
\hline 2 & $\begin{array}{l}\text { Kesesuaian penggunaan } \\
\text { strategi REACT yang } \\
\text { digunakan dengan materi- } \\
\text { materi tutorial }\end{array}$ & 4 & 4 & 4 \\
\hline 3 & $\begin{array}{l}\text { Materi-materi dari LKM } \\
\text { sesuai dengan teori-teori } \\
\text { Statistika Pendidikan }\end{array}$ & 3 & 4 & 4 \\
\hline 4 & $\begin{array}{l}\text { Penyajian materi-materi } \\
\text { dalam LKM didasarkan } \\
\text { pada strategi REACT }\end{array}$ & 4 & 3 & 4 \\
\hline 5 & $\begin{array}{l}\text { Kesesuaian penggunaan } \\
\text { strategi REACT dengan } \\
\text { karateristik } \\
\text { mahasiswa/mahasiswa UT }\end{array}$ & 4 & 4 & 4 \\
\hline 6 & $\begin{array}{l}\text { Strategi REACT yang } \\
\text { digunakan dalam LKM } \\
\text { didasarkan pada teoriti-teori } \\
\text { belajar yang kuat }\end{array}$ & 4 & 4 & 4 \\
\hline 7 & $\begin{array}{l}\text { LKM menggunakan bahasa } \\
\text { sesuai dengan kaidah yang } \\
\text { benar }\end{array}$ & 3 & 4 & 4 \\
\hline 8 & $\begin{array}{l}\text { Kesesuaian bahasa yang } \\
\text { digunakan dalam LKM } \\
\text { dengan tingkat pemahaman } \\
\text { mahasiswa }\end{array}$ & 4 & 4 & 3 \\
\hline 9 & $\begin{array}{l}\text { Kesesuaian estimasi waktu } \\
\text { dengan kompetensi yang } \\
\text { ingin dicapai }\end{array}$ & 3 & 4 & 4 \\
\hline & $\begin{array}{l}\text { Kesimpulan } \\
\text { LKM berbasis REACT }\end{array}$ & 4 & 4 & 3 \\
\hline
\end{tabular}


layak digunakan pada

tutorial matakuliah

Statistika Pendidikan

Keterangan: $1=\mathrm{STS}, 2=\mathrm{TS}, 3=\mathrm{S}$, dan $4=\mathrm{SS}$
Hasil penilaian di atas menunjukkan bahwa LKM berbasis REACT telah memenuhi kriteria valid.

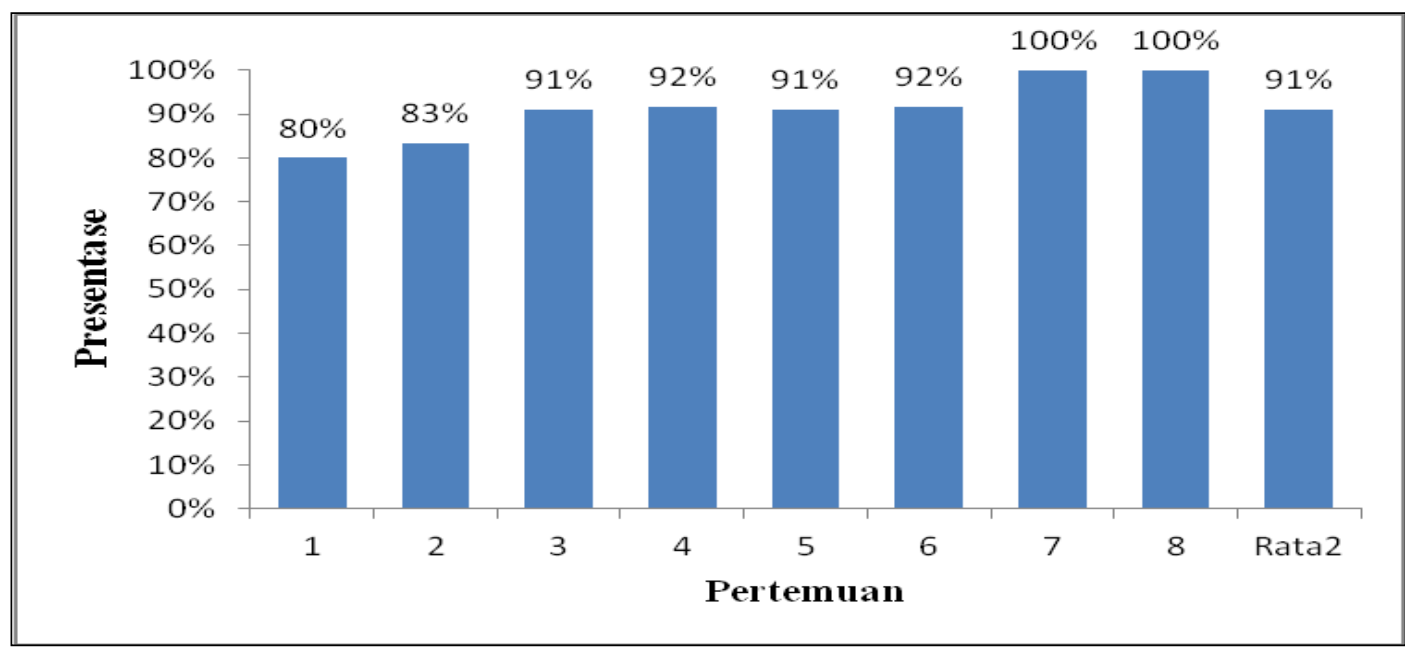

Gambar 2. Keterlaksanaan SAT per Pertemuan

Selanjutnya, LKM tersebut diimplementasi keempat puluh mahasiswa yang menjadi subjek penelitian yang terdiri dari 2 kelas A dan B dimana masing-masing kelas terdiri dari 20 mahasiswa. Pada waktu implementasi, tutor diawasi oleh tiga pengamat menggunakan lembar penilaian aktivitas tutorial. Hasilnya menunjukkan bahwa tutor dapat melaksanakan setidaknya $80 \%$ kegiatan dalam SAT di setiap pertemuan (Gambar 2).

Secara keseluruhan, semua modul dalam LKM dapat diselesaikan dalam 8 kali tutorial tatap muka. Dengan demikian, LKM berbasis REACT telah memenuhi kriteria kepraktisan.
Hasil penelitian juga menunjukkan bahwa mahasiswa dapat menjawab setidaknya $\quad 80 \%$ pertanyaan/soal/tugas dalam LKM berbasis REACT. Lebih lanjut, rata-rata hasil belajar mahasiswa sebesar 87,2 lebih dari 70 (Tabel 3).

Tabel 3. Hasil Belajar Mahasiswa UT

\begin{tabular}{|c|c|c|c|}
\hline Kelas & Rata-Rata & Min & Maks \\
\hline A & 85,8 & 73,4 & 92,8 \\
\hline B & 88,6 & 60,0 & 92,2 \\
\hline Gabungan & 87,2 & 60,0 & 92,8 \\
\hline
\end{tabular}

membagikan angket pada mahasiswa. Hasilnya menunjukkan bahwa 70\% mahasiswa berpendapat setuju atau sangat setuju bahwa LKM dapat membantu mahasiswa dalam memahami 
konsep-konsep dalam mata kuliah

Statistika Pendidikan (Tabel 4).

Tabel 4. Hasil Angket Mahasiswa

\begin{tabular}{|c|c|c|c|c|c|}
\hline \multirow[t]{2}{*}{ No } & \multirow[t]{2}{*}{ Pernyataan } & \multicolumn{4}{|c|}{ Respons (\%) } \\
\hline & & 1 & 2 & 3 & 4 \\
\hline 1 & $\begin{array}{l}\text { Anda terdorong untuk } \\
\text { mempelajari Modul secara } \\
\text { mendalam agar dapat } \\
\text { menjawab permasalahan yang } \\
\text { ada pada LKM berbasis } \\
\text { REACT }\end{array}$ & & 24 & 46 & 30 \\
\hline 2 & $\begin{array}{l}\text { Anda merasa tertantang untuk } \\
\text { belajar lebih keras dalam } \\
\text { mengikuti tutorial }\end{array}$ & & 15 & 66 & 19 \\
\hline 3 & $\begin{array}{l}\text { Anda dapat memahami } \\
\text { materi Statistik Pendidikan } \\
\text { yang dibahas dalam tutorial }\end{array}$ & & 30 & 64 & 6 \\
\hline 4 & $\begin{array}{l}\text { Anda merasa termotivasi } \\
\text { untuk mempelajari Statistik } \\
\text { Pendidikan secara mandiri }\end{array}$ & & 19 & 64 & 17 \\
\hline 5 & $\begin{array}{l}\text { Anda terdorong untuk } \\
\text { menyelesaikan soal-soal dari } \\
\text { LKM yang telah dipelajari } \\
\text { dalam pembelajaran secara } \\
\text { kelompok }\end{array}$ & & 7 & 83 & 10 \\
\hline 6 & $\begin{array}{l}\text { Anda merasa memperoleh } \\
\text { sesuatu/pengetahuan yang } \\
\text { baru selama mengikuti } \\
\text { tutorial Statistik Pendidikan }\end{array}$ & & 5 & 72 & 23 \\
\hline 7 & $\begin{array}{l}\text { Anda mengharapkan tutorial } \\
\text { matakuliah lainnya } \\
\text { menggunakan metode } \\
\text { REACT }\end{array}$ & 8 & 26 & 46 & 20 \\
\hline 8 & $\begin{array}{l}\text { Anda merasa didengarkan } \\
\text { dan diperhatikan selama } \\
\text { tutorial }\end{array}$ & & 4 & 83 & 13 \\
\hline 9 & $\begin{array}{l}\text { Tutor Anda selalu merespon } \\
\text { pertanyaan mahasiswa }\end{array}$ & & & 64 & 36 \\
\hline 10 & $\begin{array}{l}\text { Anda diarahkan Tutor selama } \\
\text { kegiatan diskusi untuk } \\
\text { menyelesaikan LKM }\end{array}$ & & & 67 & 33 \\
\hline 11 & $\begin{array}{l}\text { Anda merasa waktu cepat } \\
\text { sekali selama tutorial untuk } \\
\text { menyelesaikan soal- } \\
\text { soal/tugas-tugas dalam LKM }\end{array}$ & & 48 & 52 & \\
\hline
\end{tabular}

Keterangan: $1=\mathrm{STS}, 2=\mathrm{TS}, 3=\mathrm{S}$, dan $4=\mathrm{SS}$

Hasil-hasil tersebut menunjukkan

bahwa LKM berbasis REACT telah memenuhi kriteria keefektifan. Dengan demikian, LKM berbasis REACT telah memenuhi semua kriteria pengembangannya yaitu kevalidan, kepraktisan dan keefektifan.

Hasil penelitian menunjukkan bahwa LKM berbasis REACT dapat mendorong mahasiswa memiliki pemahaman yang baik terhadap konsepkonsep dan prosedur-prosedur dalam mata kuliah Statistika Pendidikan. Hal tersebut ditunjukkan dengan rata-rata hasil belajar mahasiswa sebesar 87,2. Ini terjadi karena pengetahuan yang baru dikaitkan dengan pengetahuan sebelumnya yang ada dalam pikiran siswa yang disebut dengan skema pengetahuan. Pengetahuan yang saling terkait membuatnya bermakna dalam pikiran mahasiswa. Mahasiswa yang memiliki pengetahuan yang bermakna akan lebih mampu dalam menyelesaikan soal-soal, tugas-tugas atau masalahmasalah matematika (Hudojo, 2005). Selain itu, strategi REACT mendorong mahasiswa untuk mengaplikasikan pengetahuannya dalam tugas-tugas yang bermakna sehingga mahasiswa dapat memiliki kebiasaan berpikir yang baik. Kebiasaan berpikir tersebut adalah berpikir kritis dan kreatif (Marzano, 1993).

Selain itu, LKM berbasis REACT juga dapat menciptakan suasana belajar yang menyenangkan bagi mahasiswa sehingga mahasiswa termotivasi dalam 
menyelesaikan tugas-tugas, soal-soal atau masalah-masalah dalam LKM baik di dalam maupun di luar kelas secara mandiri. Masalah matematika itu sendiri diartikan sebagai soal-soal yang tidak dapat diselesaikan dengan menggunakan secara langsung rumus-rumus atau prosedur-prosedur matematika tertentu (Polya, 1973, 1981; Sakshaug, Olson, \& Olson, 2002; Shumway, 1980). Tugas tutor menjadi fasilitator dan pembimbing bagi mahasiswa sehingga memiliki pengetahuan mendalam (indepth understandin). Hal tersebut karena lingkungan belajar dalam strategi REACT yang didesain sehingga mahasiswa saling bekerja sama (cooperating) baik dalam kelompok maupun diskusi kelas (Crawford, 1999).

REACT merupakan salah satu pembelajaran dalam aliran konstruktivis. Pembelajaran lainnya adalah pembelajaran kooperatif dan penemuan terbimbing. Hasil-hasil penelitian dengan pembelajaran tersebut juga menunjukkan bahwa pembelajaran konstruktivisme dapat meningkatkan pemahaman mahasiswa, kemampuan bernalar, hasil belajar, dan tingkat partisipasi mahasiswa dalan belajar. Mahasiswa juga merespons positif terhadap pembelajaran ini (Anggraini, 2012; Karnasih, \& Rahman, 2014; Widayati, 2014)

\section{Kesimpulan dan Saran}

Hasil-hasil

penelitian menunjukkan bahwa semua validator menyatakan sangat setuju atau setuju bahwa materi dari LKM sesuai dengan teori-teori Statistika Pendidikan, dan penyajian materi dalam LKM didasarkan pada strategi REACT. Jadi, LKM berbasis REACT telah memenuhi kriteria kevalidan.

Hasil penelitian juga menunjukkan bahwa tiga pengamat menyatakan bahwa tutor dapat melaksanakan setidaknya $80 \%$ kegiatan dalam SAT di setiap pertemuan, dan semua modul dalam LKM dapat diselesaikan dalam 8 kali tutorial tatap muka. Jadi, LKM berbasis REACT telah memenuhi kriteria kepraktisan.

Lebih lanjut, hasil penelitian menunjukkan bahwa mahasiswa dapat menjawab setidaknya $80 \%$ pertanyaan/soal/tugas dalam LKM berbasis REACT, rata-rata hasil belajar mahasiswa $=87,2$ (lebih dari 70), dan $70 \%$ mahasiswa setuju atau sangat setuju bahwa LKM dapat membantu mahasiswa memahami konsep-konsep Statistika Pendidikan. Jadi, LKM berbasis REACT telah memenuhi kriteria keefektifan.

\section{Pustaka}

Anggraini, V. (2012). Pengaruh Penggunaan Model 
Pembelajaran Kooperatif Tipe

Stad terhadap Pemahaman

Konsep Matematik Mahasiswa

Program Studi Pendidikan

Matematika Stkip PGRI Sumbar.

Jurnal AdMathEdu, 2(1).

CORD. (2001). The REACT strategy. diunduh dari http://www. Cord.org/the-react-strategy, pada tanggal 21 Februari 2016.

Crawford, M. L.. (1999). Teaching and Contextually.research, rationale, and Techniques for improvingstudent motivation and Achievement In Mathematics and Science. Waco, Texas. CCI publishing, Inc

CTN. (2001). Contextual Teaching Exchange, Volume 1, Number 1, August 2001.

Depdiknas. (2004). Matematika dalam Materi pelatihan terintegrasi.Jakarta: Departemen Pendidikan Nasional.

Hudojo, H. (2003). Pengembangan Kurikulum dan Pembelajaran Matematika: Malang: IMSTEP Malang.

Hudojo, H. (2005). Kapita selekta Pembelajaran Matematika. Malang: UM Malang
Jhonson. E.B. (2002). Contextual Teaching and Learning. California: Corwin Press, Inc.

Karnasih, I., \& Rahman, A. (2014). Integrasi Software Dinamis Autograph dalam Pembelajaran Matematika Menggunakan Pendekatan Penemuan Terbimbing. Jurnal AdMathEdu, $4(2)$.

Krulik, S., dkk. (2003). Teaching Mathematics in Middle Schools. A Practical Guide. Boston: Pearson Education Inc.

Kusrini, dkk. (2011). Statistika Pendidikan edisi kedua. Jakarta: Penerbit Universitas Terbuka.

Marzano, R. J., Pickering, D., \& McTighe, J. (1993). Assessing student outcomes. Alexandria VA: Association for Supervision and Curriculum Development.

Nieveen, N. (1999). Prototyping to ReachProduct Quality. Dalam van den Akker, J.Branch, RM. Gustafson, K.. Nieveen, N. \& Plomp, T. (Eds.). Dordrecht. Bostom: Kluwer Academic Publishers.

Nurhadi, dkk. (2004). Kontekstual dan Penerapannya dalam $K B K$. Malang: UM Press. 
Plomp. T. (1997). Educational \& Training System Design. Enschede, Netherlands: Faculty of Educational Science and Technology, University of Twente.

Polya, G. (1973). How to Solve It, Second Edition. New Jersey: Princeton University.

Polya, G. (1981). Mathematical Discovery: On Understanding, Learning and Teaching Problem Solving, Combined Edition. New York: John Willey \& Sons, Inc.

Sakshaug L., Olson, M. \& Olson, J. (2002). Children are Mathematical Problem Solvers. Reston, VA: NCTM, Inc.

Shumway, R. J. (1980). Research in Mathematics Education. Reston, VA: NCTM Inc.

Widayati. (2014). Efektivitas Pembelajaran Matematika dengan Model Pembelajaran Kooperatif Tipe STAD (Student Team Achievement Division) Pada Mahasiswa Semester $V$ Program Studi Pendidikan Matematika Fkip Universitas Ahmad Dahlan Yogyakarta Tahun Ajaran 2013/2014. Jurnal AdMathEdu, 4(1). 